\title{
液体炭化水素の帯電防止剈としての両性界面活性剤金属塩の作用機構*1
}

(昭 和 43 年 11 月 8 日 受理)

\author{
丸茂秀雄・二宮 守男 ${ }^{* 2}$
}

両性界面活性剂金属垥（以下 AMS と略す）の液体炭化水素の帯電防止剤としての作用機構を検討した。AMSをべンゼンに 10 〜 $100 \mathrm{ppm}$ 添加すると, 電導度は $10^{-14} \Omega^{-1} \cdot \mathrm{cm}^{-1}$ から $10^{-12}, 10^{-11} \Omega^{-1} \cdot \mathrm{cm}^{-1}$ に高くなるとともに空試験ポリエチレン管を使用 した流動帯電量は $97.6 \mu \mu \mathrm{C} / \mathrm{cm}^{3}$ から $1.2 \sim 10.3 \mu \mu \mathrm{C} / \mathrm{cm}^{3}$ に低下した。一度 AMS を添加したベンぜを流動させた後，同じ管 に空試験ベンゼンを流動させた場合にも $20 \sim 30 \mu \mu \mathrm{C} / \mathrm{cm}^{3}$ の低い带電量がえられた。一方，AMS を練り込んだホリエチレン管に 空試験ペンゼンを流動させても，ベンゼンに AMS を添加した場合と同様に流動帯電量は $2.3 \sim 6.0 \mu \mu \mathrm{C} / \mathrm{cm}^{3}$ となった。以上の結 果から、ベンゼンに添加した AMS が管壁に吸着した吸着分子層ならびにポリェチレンに練り込んで形成された表面分子層の存在 が液体の電導度とは関係なく，発電防止の作用で帯電の制御を行なったと考えられる。

\section{1 鍺言}

著者らは第 17 報1)で，两性界面活性剂金属塩（以下 AMS と 略す）は液体炭化水素に $10 \sim 100 \mathrm{ppm}$ 添加すると電導度を増大 させ，ステンレススチール管を使用した流動帯電量は空試験にく らべていちじるしく低い值を示すことを報告した。しかし，AMS を添加した液体の電導度と流動帯電量は必ずしも比例しない場合 があり, 電導度に関係なく低い帯電量がえられるのは, 液体に添 加した AMS が管壁に吸着して，この吸着分子層が带電の発生を 支配していると考えた。もしそうだとすれば，AMS を添加した ベンゼンを一度ポリエチレン管を流動させた場合には，管壁には AMS の吸着分子層が存在しているはずであり，ひきつづき空試 験のベンゼンを流動させても帯電は拈こらないことが予想され る。つまりこの場合には，電導度の低い空試験ベンゼンを使用す るので, 電導度は帯電発生の防止には関係しないことになる。

このように液体/管の界面に存在する吸着分子層が液体の帯電 防止に重要な要素であるとすれば，著者らが行なった AMSによ る合成高分子の帯電防止に打いて，AMS は表面に分子層を形成 するので2), ヘンゼンに AMSを添加するかわりにポリエチレン に練り込んで管壁に表面分子層をつくれば，発電防止の因子によ って液体の帯電防止ができると考えられる。この表面分子層はべ ンゼンによって洗いながされた場合には, 内部からの払散, 移行 で補充されるので，永久的な帯電防止が行なえる。本報では，管 壁に存在する表面分子增が発電防止の作用で夜体の带電防止がで きることを確認したので報告する。

\section{2 結果および考案}

\section{$2 \cdot 1$ 带電防止剂を添加したベンゼンの带軋}

表 1 に示す AMS を添加して空試験のポリエチレン管を流動さ せたベンゼンの流動帯電量を，ステンレススチール管を使った第 17 報1)の結果と合せて表 2 に示す。No. $433 ４ 73$ はともに 10 $100 \mathrm{ppm}$ の添加で, ベンゼンの電導度を $10^{-4} \Omega^{-1} \cdot \mathrm{cm}^{-1}$ から $10^{-12}, 10^{-11} \Omega^{-1} \cdot \mathrm{cm}^{-1}$ に高めるとともに, 流動帯電量は空試験 の $97.6 \mu \mu \mathrm{C} / \mathrm{cm}^{3}$ から $1.2 \sim 10.3 \mu \mu \mathrm{C} / \mathrm{cm}^{8}$ と効果的に低下して

\footnotetext{
*1 本報を「带電防止郕に関する研究（第 25 報）」とする．前 報（第 24 報），高井，丸茂，工化 $72 ， 947$ (1969).

*2 Hideo MARUMO, Morio NINOMIYA ライオン油脂株式会 社研究所: 東京都江戸川区平井 3 丁目.

1）丸茂, 二宮, 工化, 69, 1886 (1966).

2）丸茂，帯電防止剤，幸書房（1968） p. 125 .
}

表 1 两性界面活性剂金属塩

活 住用棈造式

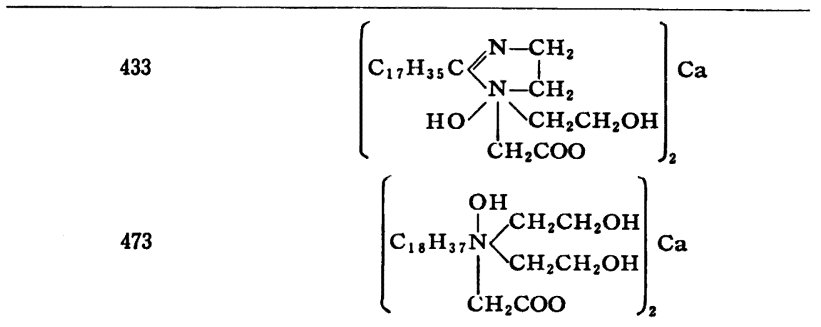

表 2 ペンゼンに AMS を添加して, ポリェチレン管を 流動させた場合の帯電

\begin{tabular}{|c|c|c|c|c|c|}
\hline \multirow{2}{*}{$\begin{array}{c}\text { 活 性 剂 } \\
\text { No. }\end{array}$} & \multicolumn{2}{|c|}{ 添 加 量 } & \multirow{2}{*}{$\begin{array}{c}\text { 管 度 } \\
\left(\Omega^{-1} \cdot \mathrm{cm}^{-1}\right)\end{array}$} & \multirow{2}{*}{ 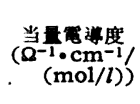 } & \multirow{2}{*}{ 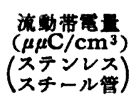 } \\
\hline & (ppm) & $(\mathrm{mol} / \mathrm{l})$ & & & \\
\hline \multirow[t]{2}{*}{ 空試龭 } & - & - & $2.0 \times 10^{-14}$ & - & $97.6(42.4)$ \\
\hline & 10 & $1.0 \times 10^{-5}$ & $1.4 \times 10^{-12}$ & $1.4 \times 10^{-7}$ & $10.3(7.5)$ \\
\hline \multirow[t]{3}{*}{433} & 50 & $5.1 \times 10^{-5}$ & $2.7 \times 10^{-12}$ & $5.3 \times 10^{-7}$ & $4.0(7.0)$ \\
\hline & 100 & $1.0 \times 10^{-4}$ & $6.5 \times 10^{-12}$ & $6.5 \times 10^{-8}$ & $1.2(1.3)$ \\
\hline & 10 & $1.4 \times 10^{-5}$ & $6.5 \times 10^{-12}$ & $4.6 \times 10^{-7}$ & 5.1 \\
\hline \multirow{2}{*}{473} & 50 & $7.1 \times 10^{-5}$ & $2.9 \times 10^{-11}$ & $4.1 \times 10^{-7}$ & 3.0 \\
\hline & 100 & $1.4 \times 10^{-4}$ & $2.4 \times 10^{-11}$ & $1.7 \times 10^{-7}$ & 2.3 \\
\hline
\end{tabular}

ポリエチレン管 : $80 \mathrm{~cm}$, ステンレススチール管 : $50 \mathrm{~cm}$

いる。

表 2 の実験を行なった後, 風乾 30 分で, 同じ管に空試験のへ ンゼンを流動させて帯電量を測定した結果を表 3 に示す。2 回目 の流動帯電量は表 2 の空試験の値と同程度となっているが, 1 回 目はかなり低い值を示し，とくに $100 \mathrm{ppm}$ 添加では 20〜30 $\mu \mu \mathrm{C} /$ $\mathrm{cm}^{3}$ と低い。このことから AMS を含有するベンゼンを一度ポ リエチレン管を流動させると, AMS の吸着がおこって AMS の 表面分子層がポリエチレン管内で形成され，この存在のために空 試験ベンゼンを流動させても帯電は発生しにくいが，2回目では 表面分子層は洗いながされているので空試験の值に近つく。使用 したベンゼンの電導度は $2.0 \times 10^{-14} \Omega^{-1} \cdot \mathrm{cm}^{-1}$ であり,さらに 1

表 3 ペンゼンに AMSを添加して流動させたポリエチレン

管に，さらに空試験ベンセンを流動させた場合の帯電

\begin{tabular}{|c|c|c|c|c|}
\hline \multirow{2}{*}{$\begin{array}{c}\text { 话 性 剤 } \\
\text { No. }\end{array}$} & \multicolumn{2}{|c|}{ 前回のベンだ染゙ } & \multicolumn{2}{|c|}{ 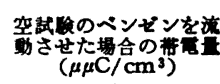 } \\
\hline & (ppm) & $(\mathrm{mol} / \mathrm{l})$ & 1 回 & 2 回 \\
\hline \multirow{3}{*}{433} & 10 & $1.0 \times 10^{-5}$ & 75.7 & 96.7 \\
\hline & 50 & $5.1 \times 10^{-5}$ & 41.5 & 86.5 \\
\hline & 100 & $1.0 \times 10^{-4}$ & 22.2 & 77.9 \\
\hline \multirow{3}{*}{473} & 10 & $1.4 \times 10^{-5}$ & 61.3 & 117.0 \\
\hline & 50 & $7.1 \times 10^{-5}$ & 52.5 & 107.0 \\
\hline & 100 & $1.4 \times 10^{-4}$ & 29.8 & 88.7 \\
\hline
\end{tabular}


回目の流動落下したものの電導度も $1.8 \times 10^{-14} \Omega^{-1} \cdot \mathrm{cm}^{-1}$ (No. 433, 1 回目）と低いので, 電導性による電荷の漏洩ではなくて発 生を抑制，防止する機構で帯電制御がなされている。

一般にベンゼンのような誘電率の低い液体が管内を流動する場 合には，水溶夜に打けるよりもはるかに厚い電気二重層が形成さ れ，電荷が広い範囲にわたって分離，分布され，流動によって携 行されるので, 流動帯電がおこると考えられている。AMS をべ ンゼンに添加した場合には電導度も高くなって電荷の漏洩の因子 も大きくなっているが, Rutgersら が が実験, 計算したように, Zn-Dips/ベンゼンでは電気二重層の王縮がおこり, 電荷の分離 分布が制限されるため, 発生が抑制される要因む大きいと考えら れる。しかし, 一度 AMS を添加したベンゼンを流した後, 空試 験のベンゼンを流動した場合には前回の AMS の表面分子層は明 らかに存在しているので, 表 3 の帯電防止の効果は表面分子層の 存在による発電防止の機構をとると考えられる。表 2 の実験を管 長をかえて行なって表 4 をえた。空試験のベンゼン，AMS を添 加したベンゼンともに管長が長くなるにしたがって流動带電量は 幾分増大する傾向がある。

表 4 ペンゼンに AMS を添加してポリエチレン管を流 動させた場合の帯電と管長

\begin{tabular}{|c|c|c|c|c|}
\hline & 性 都 & 添 & 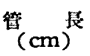 & $\begin{array}{l}\text { 流動带雪瀑 } \\
\left(\mu \mathrm{c} / \mathrm{c}^{3}\right)\end{array}$ \\
\hline \multirow{4}{*}{ 空 践 } & \multirow{4}{*}{ \& } & \multirow{4}{*}{-} & 40 & 75.8 \\
\hline & & & 80 & 97.6 \\
\hline & & & 120 & 111.3 \\
\hline & & & 160 & 121.5 \\
\hline \multirow{4}{*}{\multicolumn{2}{|c|}{433}} & \multirow{4}{*}{50} & 40 & 3.1 \\
\hline & & & 80 & 4.0 \\
\hline & & & 120 & 6.3 \\
\hline & & & 160 & 8.4 \\
\hline \multirow{4}{*}{\multicolumn{2}{|c|}{473}} & \multirow{4}{*}{50} & 40 & 2.8 \\
\hline & & & 80 & 3.0 \\
\hline & & & 120 & 4.9 \\
\hline & & & 160 & 7.5 \\
\hline
\end{tabular}

\section{$2 \cdot 2$ 带電防止剤を練り込んだポリエチレン管を 空試験ベンセ ンを流動させた場合の带電}

No. 433 を練り込んだポリエチレン管に，管長をかえて空試験 のベンゼンを流動させた場合の結果を表 5 に示す。流動帯電量は No. 433 をベンゼンに 50 ppm 添加して, 空試験 のポリエチレン管を流動 させた場合の表 4 と大体 同じである。つまり No. 433 は管に練り込んで も, ベンゼンに添加して も同梯に帯電防止効果が

表 5 AMS を練り込んだポリェチレ ン管に空試験のペンぜンを流動さ せた場合の帯電

\begin{tabular}{|c|c|}
\hline 管 $(\mathrm{cm})^{\text {長 }}$ & $\begin{array}{l}\text { 流動带電量 } \\
\left(\mu \mu \mathrm{C} / \mathrm{cm}^{3}\right)\end{array}$ \\
\hline 40 & 2.4 \\
\hline 80 & 3. 3 \\
\hline 120 & 4.8 \\
\hline 160 & 6.0 \\
\hline
\end{tabular}

認められる。管に練り込んだ場合には，流動したベンゼンの電導 度は空試験と大体同じであり，電荷の漏洩の因子ではなくて，発 生が抑制されたとしか考えられない。これは表面分子層の存在が 接触電位差を生じないようにして発生を抑制していると考えられ る。

図 1 では流下 30 分後に, さらに空試験のベンゼンを流下して 流動帯電量を測定した。これを繰返すと流動带電量は次第に高く なり， 7 回以上では一定の值を示すようになる。この值は表 2 の

3) A. J.Rutgers, M. DeSmet, G. DeMyer, Trans. Faraday Soc., 53, 393 (1957).

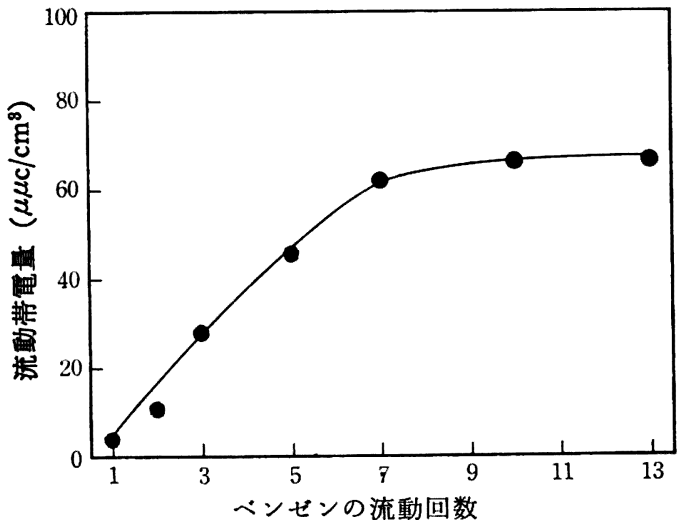

図 1 No. 433 を練り込んだポリエチレン管に空試験べ ンゼンを流した場合の帯電

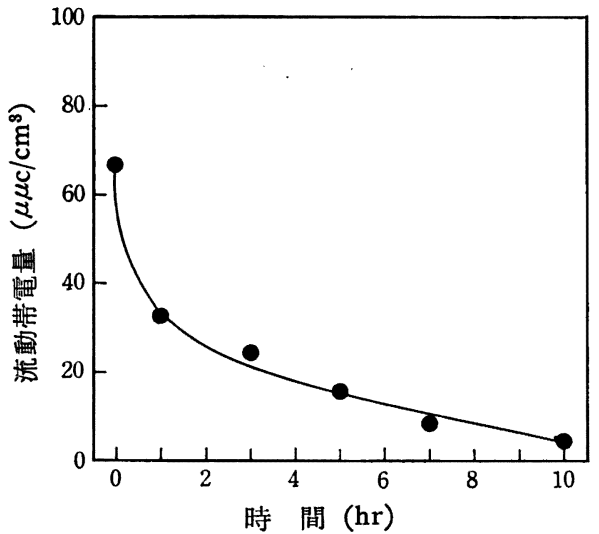

図 1 No. 433 を練り込んだポリエチレン管を $50^{\circ} \mathrm{C} k$ 加熱した後のペンゼンの帯電

空試験の值よりは低い。以上からベンゼンによって No. 433 の表 面分子層が洗いながされたことが推定される。つまり室温で 30 分以内に, 練り込まれた No. 433 は表面に拡散, 移行して表面分子 層を形成できないと考えられる。そこで空試験ベンゼンを 10 回 流した管を $50^{\circ} \mathrm{C}$ に执いて表面分子層の形成を助長すると, 図 2 の結果がえられた。ポリエチレン管の加熱時間が長くなると, 空 試験ヘンゼンの流動帯電量は低下して表 5 と同様の結果を示す。 これは No. 433 の表面分子層がふたたび形成され, 発電の抑制が なされたものと考えられる。

\section{$2 \cdot 3$ ボリエチレンの表面物性}

第 9 報4)において, No. 433 のベンゼン溶液にポリプロピレン をつけて風乾すると, 表面固有抵抗は空試験の $10^{15} \Omega$ 以上から $10^{11}, 10^{12} \Omega$ に低下して，表面分子層の形成が推定された。この 結果を表 6 に再録する。No. 433 の濃度は表 2 と同程度なので, 1 回 No. 433 を含むべンゼンを空試験のポリエチレン管に流動さ せると，表面物性とくに表面固有抵抗は表 6 ににた低下を示すと 考えられる。No. 433，473 を添加したポリエチレンを射出成形機 でシートにして, これを 別々に空試験のベンゼン につけて引上げて風乾す ると表 7 のよであり, 表面分子層は洗いながさ れて，表面固有抵抗，接 表 6 No. 433 のベンゼン溶液で処理 したポリプロピレンの表面固有抵抗

4) 丸茂, 高井, 工化, 68, 2213 (1965). 
表 7 AMS を練り込んだポリエチレンをベンゼンに浸 セキした後の表面物性

\begin{tabular}{|c|c|c|c|c|}
\hline \multirow{2}{*}{ 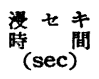 } & \multicolumn{2}{|c|}{ 表面固有抵抗 ( $\Omega$ ) } & \multicolumn{2}{|c|}{ 接触角 (水， ${ }^{\circ}$ ) } \\
\hline & No. 433 & No. 473 & No. 433 & No. 473 \\
\hline 0 & $5.7 \times 10^{10}$ & $2.4 \times 10^{10}$ & 57 & 52 \\
\hline 10 & $7.2 \times 10^{11}$ & $3.0 \times 10^{11}$ & 64 & 63 \\
\hline 20 & $2.1 \times 10^{12}$ & $4.8 \times 10^{12}$ & 69 & 67 \\
\hline 30 & $9.0 \times 10^{12}$ & $7.1 \times 10^{12}$ & 73 & 73 \\
\hline 60 & $1.5 \times 10^{14}$ & $5.7 \times 10^{13}$ & 77 & 75 \\
\hline 90 & $7.5 \times 10^{14}$ & $3.6 \times 10^{14}$ & 78 & 80 \\
\hline
\end{tabular}

RH $50 \%, 20 \mathrm{C}$ ，真空デシヶータ乾煤.

触角はいずれも低かったものが高くなる。表 7 の結果から，図 1 においても空試験ペンゼンの流動でポリエチレン管内に存在する No. 433 の分子層は洗いながされていることが説明される。

図 2 では，ポリエチレン管を $50^{\circ} \mathrm{C}$ において表面分子層の回復 をはかり，流動帯電量と関連させたが，室温ではこの回復には長 い時間が必要と考えられる。No. 433，473を練り込んだポリエチ レンシートを中性洗剤（アニオン性, ライポンF）溶夜でガーゼ でこすって洗浄して室温に放置すると，表 8 のように表面分子層 の回復には 7 日以内る要することがわかる。したがって, ポリェ チレン管に帯電防止剤を添加して，ベンゼンには添加しないで永 久的な帯電防止を行ならためには, 室温で表面分子層の回復速度 のはやい帯電防止剂をかなり多量に使用することが必要であろ ら。

表 8 AMS を練り込んだポリエチレンの表面物性

\begin{tabular}{|c|c|c|c|c|c|c|c|}
\hline \multirow{2}{*}{ 条 } & \multirow[t]{2}{*}{ 件 } & \multicolumn{2}{|c|}{ 表面固有抵抗 } & \multicolumn{2}{|c|}{ 接 触。” $^{\text {角 }}$} & \multicolumn{2}{|c|}{$\begin{array}{l}\text { 觧電場带電半娍期 } \\
\text { (sec) }\end{array}$} \\
\hline & & No. 433 & No. 473 & No. 433 & No. 473 & No. 433 & No. 473 \\
\hline \multicolumn{2}{|c|}{ 成形後 2(day) } & $5.7 \times 10^{10}$ & $2.4 \times 10^{10}$ & 57 & 52 & 0.4 & 0.2 \\
\hline \multirow{4}{*}{$\begin{array}{l}\text { 洗 } \\
\text { 潇 } \\
\text { 後 }\end{array}$} & $2 " 1$ & & & & & & $>14$ \\
\hline & 5 " & & & 67 & & $>1$ & 10.0 \\
\hline & " & & & 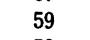 & & & 1.0 \\
\hline & & $5.0 \times 10^{10}$ & $1.5 \times 10^{10}$ & 58 & 54 & 0.8 & 0.2 \\
\hline
\end{tabular}

\section{$2 \cdot 4$ 液体の接触面皘亡流動带電}

本報の実験では, 帯電防止剤は管壁に存在する表面分子層によ って帯電の発生を抑制していると考えた。実際にはKlinkenberg らの大規模な実験では少量の帯電防止剂で帯電防止が行なわれる が，本報と同じ方法で行なった実験室の実験ではかなり多量に使 用しないと流動帯電量は低くなっていない2)。例えば, 表 9 のよ らである。

液体量を $70 \mathrm{~cm}^{3}$ から $700 \mathrm{~cm}^{3}$ にして行ならと表 10 のようで あり, 液体の容量当りの接触面積が小さい $700 \mathrm{~cm}^{3}$ の場合は, 流 動帯電量はいくらか低い傾向がみられる。表 9 に示す Klinkenberg らの大規模な実験の接触面積は大体 $0.01 \mathrm{~cm}^{2} / \mathrm{cm}^{3}$ で, 本 報での実験の $1.13 \sim 4.47 \mathrm{~cm}^{2} / \mathrm{cm}^{8}$ にくらべるときわめて小さ い。したがって，実際のタンク，管では表 2 に示すよりも少ない AMS の添加で帯電防止効果がえられ，また AMSを練り込んた 場合にも低い帯電量が期待される。

\begin{tabular}{|c|c|c|c|}
\hline $\begin{array}{c}\mathrm{Cr}-\mathrm{AC} \text { 婊度 } \\
(\mathrm{mol} / \mathrm{l})\end{array}$ & $\begin{array}{c}\text { 電 造 度 } \\
\left(\Omega^{-1} \cdot \mathrm{cm}^{-1}\right)\end{array}$ & 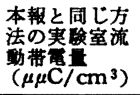 & $\begin{array}{c}\text { 带 電 圧 } \\
(\mathrm{kV} / \mathrm{m})\end{array}$ \\
\hline $6 \times 10^{-19}$ & $2.2 \times 10^{-14}$ & $<+1$ & +1.0 \\
\hline $2 \times 10^{-9}$ & $2.7 \times 10^{-14}$ & -1 & +0.1 \\
\hline $10^{-8}$ & $1.0 \times 10^{-13}$ & -14 & +0.3 \\
\hline $3 \times 10^{-8}$ & $2.7 \times 10^{-13}$ & -21 & +0.03 \\
\hline $10^{-7}$ & $9.0 \times 10^{-13}$ & -40 & +0.04 \\
\hline $3 \times 10^{-7}$ & $1.5 \times 10^{-12}$ & -75 & +0.04 \\
\hline $10^{-6}$ & $5.0 \times 10^{-12}$ & -22 & $<+0.04$ \\
\hline
\end{tabular}

表 10 液体の接触面積と流動帯電量

\begin{tabular}{|c|c|c|c|c|}
\hline $\begin{array}{l}\text { ポリエチレ } \\
\text { ン管 }\end{array}$ & 没 ${ }_{\left(\mathrm{cm}^{3}\right)^{\mathrm{n}}}^{\text {量 }}$ & $\begin{array}{l}\text { 接触面皘 } \\
\left(\mathrm{cm}^{2} / \mathrm{cm}^{3}\right)\end{array}$ & $\begin{array}{l}\text { No. } 433 \text { 添加 } \\
\text { 量 (ppm) }\end{array}$ & $\begin{array}{l}\text { 滇偊带電量 } \\
\left(\mu \mu \mathrm{C} / \mathrm{cm}^{3}\right)\end{array}$ \\
\hline \multirow{2}{*}{ 空武殹品 } & 70 & 4.47 & $\begin{array}{r}\overline{10} \\
50 \\
100\end{array}$ & $\begin{array}{r}97.6 \\
10.3 \\
4.0 \\
1.2\end{array}$ \\
\hline & 700 & 1.13 & $\begin{array}{r}\overline{10} \\
50 \\
100\end{array}$ & $\begin{array}{r}83.0 \\
6.9 \\
2.8 \\
1.2\end{array}$ \\
\hline 带電防止品 & $\begin{array}{r}70 \\
700\end{array}$ & $\begin{array}{l}4.47 \\
1.13\end{array}$ & $\overline{-}$ & $\begin{array}{l}3.3 \\
2.8\end{array}$ \\
\hline
\end{tabular}

3 実験

$3 \cdot 1$ 実験 試料

ベンゼンは試薬特級を使用した。AMS は表 1 に示すように, No. 433 は第 3 報5) で合成したもの, No. 473 は第 21 報6)で使用 したものである。ポリエチレンはハイゼックス $6100 \mathrm{M}$ (三井石 油化学(株)）を使用して, AMS 1.0\% 添加品および空試験品を 作成した。

（1）シート：スクリュー型射出成形機（名機製作所） シリンダー温度・180〜200 ${ }^{\circ} \mathrm{C}$

金型温度 $\cdot 65 \sim 70^{\circ} \mathrm{C}$ $60 \times 40 \times 1 \mathrm{~mm}$

（2）管: $60 \mathrm{~mm}$ クロスヘッドダイ押出成形機（モダンマシナ リー)

シリンダー温度・180 200 20

ダイ温度・ $180^{\circ} \mathrm{C}$

内径・水銀重量法で表 11 のように测定した。 AMS 練り込み品 $3.78 \pm 0.02 \mathrm{~mm}$, 空試験品 $3.76 \pm 0.02 \mathrm{~mm}$ 切断面は完全な円形のものをえらんで使用した。 表 11 ポリェチレン管の内径

\begin{tabular}{|c|c|c|c|}
\hline ボリエチレン管 & $\begin{array}{c}\text { 水鋇柱の辰さ } \\
(\mathrm{cm})\end{array}$ & 水銀重 & 管 $(\mathrm{cm})$ 径 \\
\hline \multirow{7}{*}{ 空 武 些 品 } & 8.55 & 12.9048 & 0.376 \\
\hline & 8.92 & 13. 3916 & 0.375 \\
\hline & 10.05 & 15.1687 & 0.376 \\
\hline & 11.25 & 17.1611 & 0.378 \\
\hline & 11.93 & 18.0063 & 0.376 \\
\hline & 13.51 & 20.2826 & 0.375 \\
\hline & 13.88 & 20.8262 & 0.375 \\
\hline \multirow{7}{*}{ 带雪防止品 } & 7.43 & 11.3939 & 0.379 \\
\hline & 8.61 & 12.9953 & 0.376 \\
\hline & 8.90 & 17.5763 & 0.378 \\
\hline & 9.85 & 15.0255 & 0.378 \\
\hline & 11.33 & 17.1916 & 0.377 \\
\hline & 14.65 & 22.3476 & 0.378 \\
\hline & 14.87 & 22.5630 & 0.377 \\
\hline
\end{tabular}

\section{$3 \cdot 2$ 溶液の調整}

No. 433, 473 をベンゼンに $100 \mathrm{ppm}$ 溶解し, これからメスフ ラスコを使って $50,10 \mathrm{ppm}$ の溶液をつくった。

\section{$3 \cdot 3$ 流動带電量測定}

第 17 報1)に同じ。ただし金属（ステンレスステール）製の上 部の漏斗にポリエチレン管を接続した。 $70 \mathrm{~cm}^{3}$ のベンゼンが 80 $\mathrm{cm}$ の管を流動する時間は 10 秒で, レイノルズ数は 3280 であ る。振動容量型電位計 TR-84 B 型（タケダ 理研工業株式会社） 使用の 3 回平均値。

\section{4 電等度測定}

第 17 報1) に同じ。JIS C-2320 の絶縁油試験電極 TR-44 型

5）丸茂, 高井, 工化, 68，2186（1965）.

6）丸茂, 紊藤, 二宮, 渡辺, 油化学, 16，30（1967）. 
(タケダ理研工業株式会社), 振動容量型電位計 TR-84 B 型（タ ケダ理研工業株式会社）使用の印加電圧 $500 \mathrm{~V}, 1$ 分値。

3.5 表面物性

(1) 表面固有抵抗

第 1 報7) に同じ。極超絶縁計 SM-10 型（東亜電波工業（株)） 使用の印加電圧 $500 \mathrm{~V}, 1$ 分値。

（2）接触角

7）丸茂, 高井, 油化学, 14, 571（1965）.
第 2 報8) に同じ。ゴニオメーター（エルマ光学（株））使用の 10 回平均値。蒸留水。

（3）静電場带電

第 14 報9) に同じ。オネストメーター（(株）穴戸商会）使用。 (昭和 42 年 6 月, 第 12 回静電気研究発表会講演) 本報の発表を許可されたライオン油脂株式会社に感謝する。

8）丸茂, 高井, 油化学, 14；619（1965).

9）丸茂, 高井, 齐藤, 荻田, 工化, 69, 1504 (1966).

\section{アソビスイソブチロニトリルの熱分解}

(昭 和 43 年 5 月 29 日 受 理)

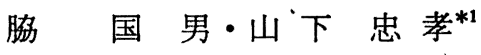

フソビスイソブチロニトリルを固体で熱分解した。示差熱分析により分解状熊を追䟣し，他の発泡剤のように，20 種の有機酸， 無機酸, その他の試薬による添加剤の影敏を調べたが, ほとんど分解温度の变化はみられなかった。しかし融点の近い試薬では発 熱ビークに異状がみられた。分解速度は発生ガスの圧力測定と示差熱分析によって行ない, みかけの活性化ェネルギーはそれぞれ $29.6,29.9 \mathrm{kcal} / \mathrm{mol}$ であった。压力法による場合, 融点前後に相当する温度領域 $90 \sim 98^{\circ} \mathrm{C}, 100 \sim 110^{\circ} \mathrm{C}$ の $\log k$ 対 $1 / T$ は平 行線になり， $\Delta S^{*}$ は 6.7, 7.1 e. u. であった。この相違は分解が固相・液相過程と液相に基つくるのと思われる。生成物は熱分 解ガスクロマトクララフーと赤外吸収スペクトルによって確認したが, 前者による定量結果は窒素 $100 \%$, テトラメチルサタシノ ニトリル 85\%, イソブチロニトリル 15.3\%,メタクリロニトリル 14.5\%であった。この結果，かこ効果による生成ラジルの

二量化反応が不均化反応をはるかに上まわっていると推定される。

\section{1 楮亩}

アゾビスイソブチロニトリル（以下 AIBN とする）がビニル

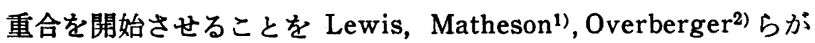
発表して以来, 一連のアゾビスニトリル類の合成, 分解に関する 研究が行なわれている。AIBN はラジカル重合の開始剤としてば かりでなく, 加熱による窒素ガスの発生を利用して発泡剤として 使用されているので, 分解機構に関しては数多くの研究が報告さ れているが，すへて溶液中におけるるのであって，固相あるいは 融解状態の直接分解に関する報告は見当らない。AIBN は熱的に 不安定で室温保存中にす分解してその性能が劣化し，とくに 100 ${ }^{\circ} \mathrm{C}$ 以上では融解一分解により高発熱分解をおこす。著者らは固相 に怙ける熱的特性および分解条件を検討した。すなわち示差熱分 析による熱的特珄の追跡と, 固相および融解時の分解速度と, 分 解温度以上の温度での生成物の定性, 定量を行ない, 固相分解の 機構を溶媒中のそれと比較して検討した。

\section{2 実 験 方 法}

$2 \cdot 1$ 試 料

市販の特級 AIBN をメタノールで $30^{\circ} \mathrm{C}$ 以下で 2 回再結晶し て使用した。

*1 Kunio WAKI, Tadataka YAMASHITA 東洋大学工学部 応用化学科：川越市鯨井.

1) F.M. Lewis, M.S. Matheson, J. Am. Chem. Soc., 71, 747 (1949).

2) C. G. Overberger, M. T. O'Shaughnessy, H. Shalit, J. Am. Chem. Soc., 71, 2661 (1949).

\section{$2 \cdot 2$ 熱的特性}

示差熱分析（以下 DTA とする）を用いて熱的特性を追跡し た。DTA 装置は島津 DT 10 型で, 加熱速度は $2 \sim 14^{\circ} \mathrm{C} / \mathrm{min}$, sense $\pm 100 \sim 250 \mu \mathrm{V}$, 雾囲気は空気中で行ない, 試料量は 2〜 $15 \mathrm{mg}$ であった。充填法は通常, サンドイッチ法, あるいは二 重法が使用されているが, 本実験では標準側はブランクにして, 試料側も中性物質（例えば $\alpha$-アルミナ等）で希积せずに測定し たが，良好な基準線が得られたのでこの方法によった。

試料の粒度は AIBN および添加剤ともに 150〜200 mesh のむ のを使用した。3.1 に述へる混合試料中の AIBN の量は, 一定 になるように添加剤の混合比が大となるにしたがい，混合陚料量 を増加させた。表 1 に，用いた添加剤と混合比を掲げた。

\section{$2 \cdot 3$ 分解速度の測定}

温度精度 $\pm 0.2^{\circ} \mathrm{C}$ 以内のアルミナブロックの等温分解炉で, $80 \sim 98^{\circ} \mathrm{C}$ および $100 \sim 110^{\circ} \mathrm{C}$ までの融解前後の二領域について 一定圧に保った Farmer の装固 ${ }^{3)}$ と、これを改良した図 1 のよ5 な分解管を用いて, 試料の分解による発生ガスの圧力変化を追跡 した。この場合真空中で測定を行ならのが望ましいが，分解物の 昇華, 蒸発による妨害で測定に誤差が大きくなるため，大気圧に 近い圧力で測定した。室温で $1 \mathrm{mmHg}$ 以下に減圧し，次いでピ ロガロール液を通した窒素ガスを導き, 初圧 $400 \mathrm{mmHg}$ から時 間による圧の変化を追跡した。時間一圧力曲線から反応速度式を 求めて， みかけの活性化エネルギー $\left(E_{\mathrm{a}}\right)$ を算出した。また, DTA に打る AIBN の発熱分解ピーク温度と昇温速度とから,

3) R. C. Farmer, J. Chem. Soc., 1920, 1420. 